\title{
Clinical Study of the Use of the New Aminoglycoside Tobramycin for Therapy of Infections Due to Gram-Negative Bacteria
}

\author{
GABRIEL. JAFFE, WILLIAM RAVREBY, BURT R. MEYERS, AND SHALOM Z. HIRSCHMAN \\ Division of Infectious Diseases, Department of Medicine, The Mount Sinai School of Medicine of the City \\ University of New York, New York 10029
}

Received for publication 25 June 1973

\begin{abstract}
Tobramycin, a new aminoglycoside antimicrobial, was evaluated as therapy for infections due to gram-negative bacilli in 15 seriously ill patients with underlying diseases. Three of 10 patients with gram-negative bacteremias also had urinary tract infections. Two patients had respiratory tract infections, one had cellulitis, one had a urinary tract infection, and another had septic phlebitis. Twelve patients were cured of their infections. Eosinophilia was observed in one patient and another developed superinfection with Staphylococcus aureus after 6 days of tobramycin therapy. There were five isolates of Escherichia coli, five of Klebsiella sp., two of Pseudomonas sp., and one each of Enterobacter agglomerans, Serratia marcescens, and Enterobacter cloacae. The average serum concentration of tobramycin $2 \mathrm{~h}$ after a parenteral dose of 1.0 to $1.5 \mathrm{mg} / \mathrm{kg}$ was 5.1 $\mu \mathrm{g} / \mathrm{ml}$; higher concentrations of tobramycin were present in urine. Tobramycin proved to be an effective antimicrobial in these patients.
\end{abstract}

The incidence of bacteremia with gram-negative bacilli has increased markedly during the last 20 years. Factors responsible for this increase include a larger elderly population with concomitant chronic diseases, the suppression of host defenses by chemotherapeutic agents, the more frequent use of instrumentation and surgical procedures, and changes in bacterial flora caused by a burgeoning variety of antimicrobial agents $(1,8-10,15,29)$.

The increasing frequency and associated high mortality of infections caused by gram-negative bacilli have lead to a continuing search for effective antimicrobial agents. Gentamicin, an aminoglycoside, hitherto has provided the most efficacious therapy for infections due to gramnegative bacilli $(3,11,14,18)$. Tobramycin is a new aminoglycoside with an in vitro spectrum of activity against aerobic gram-negative bacilli similar to gentamicin $(5,6,19)$. However, tobramycin appears to have greater activity than gentamicin against a significant number of pseudomonas strains $(5,6,19)$. We have investigated the clinical efficacy of tobramycin for therapy of hospitalized patients seriously ill with infections due to gram-negative bacilli.

\section{MATERIALS AND METHODS}

Fifteen patients admitted to The Mount Sinai Medical Center during the period November 1971 to March 1973 in whom infection due to gram-negative bacteria was suspected, or gram-negative organisms were isolated from culture material, received tobramycin parenterally at a dose of 1 to $1.5 \mathrm{mg} / \mathrm{kg}$ every $8 \mathrm{~h}$ or more. Fourteen of these patients did not receive prior antimicrobial therapy; tobramycin was the only antimicrobial agent given to these 15 patients for therapy of an infection due to a gram-negative bacterium. Gram-negative bacteria were isolated and identified from cultured specimens by standard methods in the Department of Diagnostic Microbiology of The Mount Sinai Medical Center. The minimum inhibitory (MIC) and minimum bactericidal concentrations (MBC) of tobramycin for the various gram-negative organisms were determined by a twofold tube dilution method as previously described (19). During the course of therapy, samples of serum and urine periodically were assayed for tobramycin concentration by the penicylinder method (20).

Patients were observed for clinical response to therapy and for sterilization of the infected site. The patient was considered cured of his infection if clinical symptoms abated, the infected site was sterilized, and there was no recurrence of the infection. Prior to, during, and after completion of tobramycin therapy a complete hemogram, blood urea nitrogen, serum creatinine, electrolytes, bilirubin, and alkaline phosphatase, serum glutamic oxaloacetic transaminase, serum glutamic pyruvic transaminase, and urinalysis 


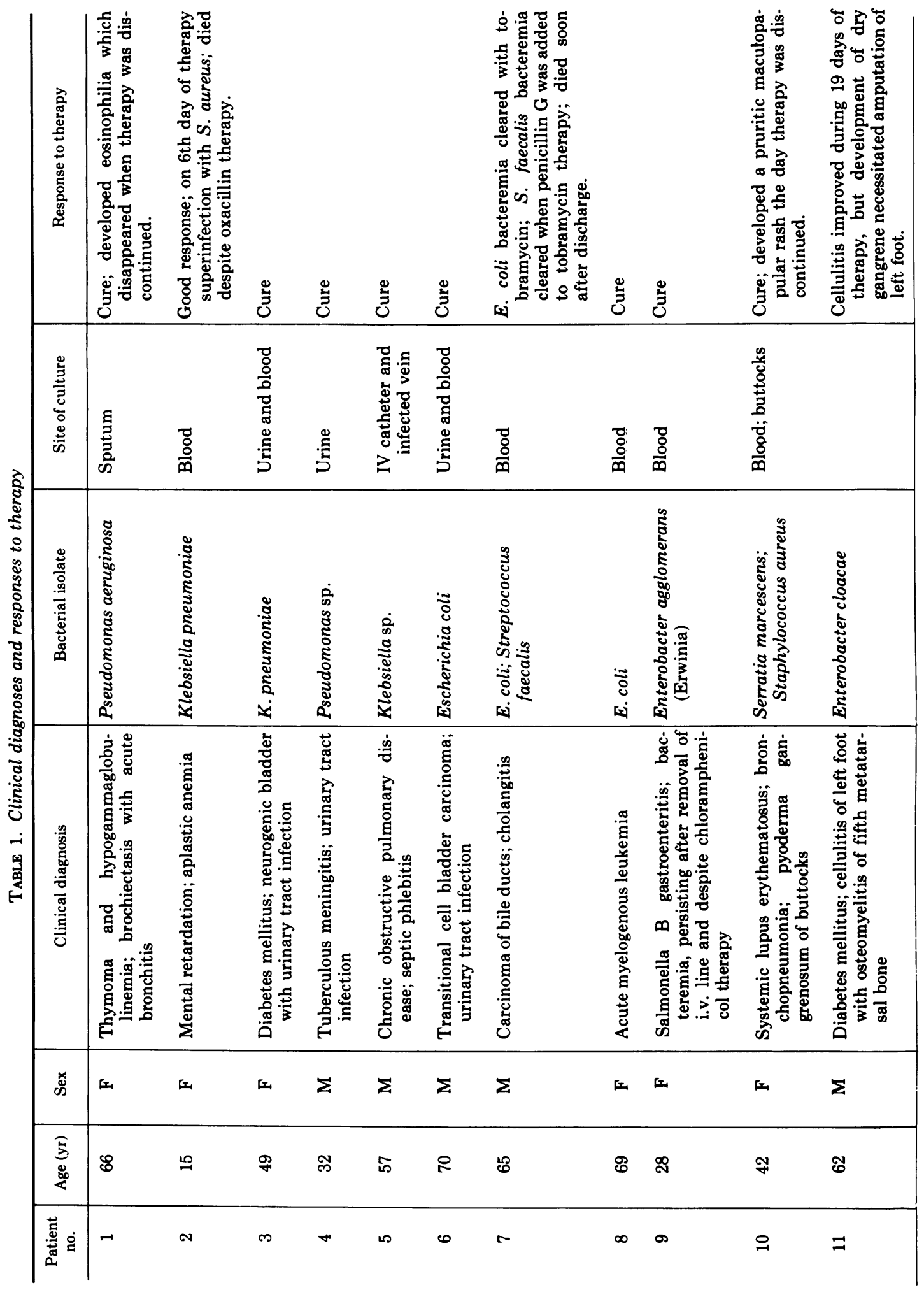




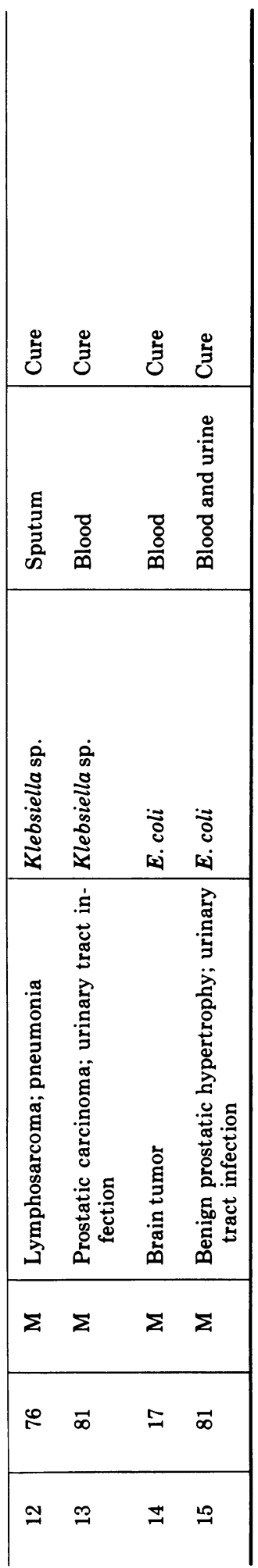

were obtained. Whenever possible, audiograms were monitored at similar intervals.

\section{RESULTS}

Bacterial isolates. There were five isolates of Escherichia coli, three from blood cultures and two from both blood and urine cultures (Table 1); four of the five isolates were inhibited by $3 \mu \mathrm{g}$ or less of tobramycin per $\mathrm{ml}$ (Table 2). The five isolates of Klebsiella sp. were inhibited by $\leq 1.5$ $\mu \mathrm{g} / \mathrm{ml}$ (Table 2). Two of these isolates were obtained from blood cultures, one from both blood and urine cultures, one from sputum cultures, and another from an abscess surrounding an infected vein (Table 1). One of the two strains of Pseudomonas was isolated from sputum cultures and the other from urine cultures. One isolate each of Enterobacter agglomerans (Erwinia) and Serratia marcescens was obtained from blood cultures; the isolate of $E n$ terobacter cloacae was grown from the aspirate of a cellulitis. One patient had both a gramnegative organism, $E$. coli, and a gram-positive organism, Streptococcus faecalis, isolated from blood cultures (Table 1).

Patients treated. Fifteen patients, nine males and six females, ranging in ages from 15 to 81 years, received tobramycin (Table 1). All patients were seriously ill with underlying diseases.

Ten patients had bacteremia; three of these patients had urinary tract infections (Table 1). Two patients (patients 1 and 12) had pulmonary infections with consistent heavy growth of a gram-negative bacterium from sputum cultures. Both patients responded well to therapy. Both gram-negative and gram-positive organisms were isolated from two patients. Patient 10 had bacteremia due to Serratia marcescens and pyoderma gangrenosum of the buttocks due to Staphylococcus aureus. Patient 7 had bacteremia with both $E$. coli and Streptococcus faecalis. After the bacteremia due to $E$. coli cleared, penicillin $\mathrm{G}$ was administered in addition to tobramycin for therapy of bacteremia due to $S$. faecalis. Except for this patient, patient 2 who received oxacillin for therapy of a superinfection due to $S$. aureus, and patient 9 who showed no response to chloramphenicol therapy, tobramycin was the only antimicrobial agent administered to the patients.

Twelve patients were cured of their infections (Table 1). Patient 2 had a good initial clinical response to tobramycin therapy but developed superinfection with $S$. aureus on the sixth day of therapy.

Patient 1 developed eosinophilia during to- 
TABLE 2. Bacteriological and pharmacological data

\begin{tabular}{|c|c|c|c|c|c|c|c|c|c|c|c|c|}
\hline \multirow{3}{*}{$\begin{array}{c}\mathrm{Pa}- \\
\text { tient } \\
\text { no. }\end{array}$} & \multirow{3}{*}{$\begin{array}{c}\text { Day of } \\
\text { ther- } \\
\text { apy }\end{array}$} & \multirow{3}{*}{ Bacterial isolate } & \multirow{3}{*}{$\begin{array}{c}\mathrm{MIC} \\
(\mu \mathrm{g} / \mathrm{ml})\end{array}$} & \multirow{3}{*}{$\begin{array}{r}\mathrm{MBC} \\
(\mu \mathrm{g} / \mathrm{ml})\end{array}$} & \multirow{3}{*}{$\begin{array}{c}\text { Dose of } \\
\text { tobramycin }\end{array}$} & \multirow{3}{*}{$\begin{array}{c}\text { Route } \\
\text { of in. } \\
\text { ocula- } \\
\text { tion }\end{array}$} & \multirow{3}{*}{$\begin{array}{c}\text { BUN } \\
(\mathrm{mg} / \\
100 \mathrm{ml})\end{array}$} & \multirow{3}{*}{$\begin{array}{c}\text { Creati- } \\
\text { nine } \\
(\mathrm{mg} / \\
100 \mathrm{ml})\end{array}$} & \multicolumn{4}{|c|}{$\begin{array}{l}\text { Tobramycin concn } \\
\qquad(\mu \mathrm{g} / \mathrm{ml})\end{array}$} \\
\hline & & & & & & & & & \multicolumn{2}{|c|}{ Serum } & \multicolumn{2}{|c|}{ Urine } \\
\hline & & & & & & & & & $2 \mathrm{~h}$ & $8 \mathrm{~h}$ & $2 \mathrm{~h}$ & $8 \mathrm{~h}$ \\
\hline 1 & $\begin{array}{l}1 \\
3 \\
5\end{array}$ & $\begin{array}{l}\text { Pseudomonas aeru- } \\
\quad \text { ginosa }\end{array}$ & & & $50 \mathrm{mg} \mathrm{q} 8 \mathrm{~h}$ & i.m. & $\begin{array}{l}13 \\
13\end{array}$ & & $\begin{array}{l}7.3 \\
6.7 \\
7.3\end{array}$ & $\begin{array}{l}1.8 \\
6.4 \\
2.4\end{array}$ & & \\
\hline 2 & $\begin{array}{l}1 \\
3 \\
5\end{array}$ & $K$. pneumoniae & 0.38 & 0.38 & $98 \mathrm{mg} \mathrm{q} 8 \mathrm{~h}$ & i.v. & $\begin{array}{r}10 \\
10 \\
9\end{array}$ & $\begin{array}{l}0.8 \\
0.7 \\
0.7\end{array}$ & $\begin{array}{l}2.5 \\
2.8 \\
0.16\end{array}$ & $\begin{array}{l}0.1 \\
0.86 \\
0.1\end{array}$ & $\begin{array}{r}60.2 \\
4.6 \\
\end{array}$ & \\
\hline 3 & $\begin{array}{l}1 \\
3 \\
5\end{array}$ & K. pneumoniae & 1.5 & 1.5 & $60 \mathrm{mg} \mathrm{q} 8 \mathrm{~h}$ & i.v. & $\begin{array}{l}12 \\
12\end{array}$ & $\begin{array}{l}1.6 \\
1.3\end{array}$ & $\begin{array}{r}10.8 \\
1.5 \\
1.9\end{array}$ & $\begin{array}{l}4.5 \\
0.66 \\
1.0\end{array}$ & $\begin{array}{l}10.5 \\
12.5\end{array}$ & \\
\hline 4 & $\begin{array}{l}1 \\
3 \\
5\end{array}$ & Pseudomonas sp. & 0.75 & 3.0 & $55 \mathrm{mg} \mathrm{q} 8 \mathrm{~h}$ & i.v. & $\begin{array}{l}6.0 \\
5.0\end{array}$ & $\begin{array}{l}1.0 \\
0.7\end{array}$ & $\begin{array}{r}2.6 \\
11.5 \\
11.1\end{array}$ & $\begin{array}{r}3.0 \\
10.0 \\
6.6\end{array}$ & 10.7 & \\
\hline 5 & $\begin{array}{l}1 \\
3 \\
5\end{array}$ & Klebsiella sp. & 1.2 & 1.2 & $80 \mathrm{mg} \mathrm{q} 8 \mathrm{~h}$ & i.v. & $\begin{array}{l}17 \\
18 \\
17\end{array}$ & & $\begin{array}{l}2.7 \\
5.0 \\
3.3\end{array}$ & $\begin{array}{l}0.76 \\
1.68\end{array}$ & & \\
\hline 6 & $\begin{array}{l}1 \\
3 \\
5\end{array}$ & Escherichia coli & 3.0 & & $60 \mathrm{mg} \mathrm{q} 8 \mathrm{~h}$ & i.v. & $\begin{array}{l}23 \\
24 \\
26\end{array}$ & $\begin{array}{l}1.6 \\
1.3 \\
1.8\end{array}$ & $\begin{array}{l}0.66 \\
2.5 \\
2.9\end{array}$ & & & \\
\hline 7 & $\begin{array}{l}1 \\
3 \\
5\end{array}$ & E. coli & 3.0 & & $90 \mathrm{mg} \mathrm{q} 8 \mathrm{~h}$ & i.v. & $\begin{array}{l}10 \\
10 \\
10\end{array}$ & $\begin{array}{l}0.75 \\
0.75 \\
0.75\end{array}$ & $\begin{array}{l}3.0 \\
2.5 \\
7.4\end{array}$ & $\begin{array}{l}1.3 \\
0.6 \\
7.0\end{array}$ & 11.2 & \\
\hline 8 & $\begin{array}{l}1 \\
3 \\
5\end{array}$ & E. coli & 1.25 & 1.25 & $60 \mathrm{mg} \mathrm{q} 8 \mathrm{~h}$ & i.v. & $\begin{array}{r}9 \\
21 \\
8\end{array}$ & $\begin{array}{l}0.9 \\
1.1 \\
0.7\end{array}$ & $\begin{array}{l}6.6 \\
1.1 \\
2.2\end{array}$ & $\begin{array}{l}0.59 \\
0.68 \\
0.68\end{array}$ & & \\
\hline 9 & $\begin{array}{l}1 \\
3 \\
5\end{array}$ & $\begin{array}{l}\text { Enterobacterag- } \\
\text { glomerans }\end{array}$ & $<1.5$ & $<1.5$ & $75 \mathrm{mg} \mathrm{q} 8 \mathrm{~h}$ & i.m. & $\begin{array}{l}5.0 \\
5.0 \\
5.0\end{array}$ & $\begin{array}{l}0.9 \\
0.9\end{array}$ & $\begin{array}{l}1.52 \\
1.20 \\
1.20\end{array}$ & $\begin{array}{l}0.86 \\
0.00 \\
0.74\end{array}$ & $\begin{array}{l}22.0 \\
25.6 \\
24.0\end{array}$ & $\begin{array}{l}80.0 \\
62.4\end{array}$ \\
\hline 10 & $\begin{array}{l}1 \\
3 \\
5\end{array}$ & Serratia marcescens & 10.0 & $>10.0$ & $75 \mathrm{mg} \mathrm{q} 8 \mathrm{~h}$ & i.m. & $\begin{array}{l}30 \\
33 \\
27\end{array}$ & $\begin{array}{l}0.8 \\
1.0 \\
0.8\end{array}$ & $\begin{array}{r}3.4 \\
11.0\end{array}$ & $\begin{array}{l}1.2 \\
0.00\end{array}$ & $\begin{array}{l}36 \\
37\end{array}$ & $\begin{array}{r}8.5 \\
16.0\end{array}$ \\
\hline 11 & $\begin{array}{l}1 \\
3 \\
5\end{array}$ & E. cloacae & 0.37 & 3.3 & $120 \mathrm{mg} \mathrm{q} 12 \mathrm{~h}$ & i.m. & $\begin{array}{l}25 \\
23\end{array}$ & $\begin{array}{l}1.4 \\
1.5\end{array}$ & 6.2 & & & \\
\hline 12 & $\begin{array}{l}1 \\
3 \\
5\end{array}$ & Klebsiella sp. & 0.75 & 0.75 & $100 \mathrm{mg} \mathrm{q} 8 \mathrm{~h}$ & i.v. & $\begin{array}{l}28 \\
25 \\
20\end{array}$ & $\begin{array}{l}1.0 \\
1.0 \\
1.0\end{array}$ & $\begin{array}{r}20.0 \\
3.4 \\
6.4\end{array}$ & $\begin{array}{l}1.95 \\
1.40 \\
1.58\end{array}$ & $\begin{array}{l}80 \\
48\end{array}$ & $\begin{array}{r}60.0 \\
7.8\end{array}$ \\
\hline 13 & $\begin{array}{l}1 \\
3 \\
5\end{array}$ & Klebsiella sp. & 0.75 & 0.75 & $120 \mathrm{mg} \mathrm{q} 8 \mathrm{~h}$ & i.v. & $\begin{array}{l}21 \\
21\end{array}$ & $\begin{array}{l}1.0 \\
1.1\end{array}$ & $\begin{array}{l}3.5 \\
9.2\end{array}$ & $\begin{array}{l}4.06 \\
2.18\end{array}$ & $\begin{array}{l}350 \\
600\end{array}$ & 240 \\
\hline 14 & $\begin{array}{l}1 \\
3 \\
5\end{array}$ & E. coli & 6.25 & 6.25 & $75 \mathrm{mg} \mathrm{q} 8 \mathrm{~h}$ & i.v. & $\begin{array}{l}8 \\
6 \\
8\end{array}$ & $\begin{array}{l}0.6 \\
0.7 \\
0.6\end{array}$ & & & & \\
\hline 15 & $\begin{array}{l}1 \\
3 \\
5\end{array}$ & E. coli & 0.75 & 1.5 & $\begin{array}{l}120 \mathrm{mg} \mathrm{q} 24 \mathrm{~h} \\
120 \mathrm{mg} \mathrm{q} 16 \mathrm{~h} \\
120 \mathrm{mg} \mathrm{q} 12 \mathrm{~h}\end{array}$ & $\begin{array}{l}\text { i.v. } \\
\text { i.v. } \\
\text { i.v. }\end{array}$ & $\begin{array}{r}127 \\
83 \\
54\end{array}$ & $\begin{array}{l}2.4 \\
1.6\end{array}$ & 9.95 & 5.0 & 3.9 & 3.0 \\
\hline
\end{tabular}

${ }^{a}$ Abbreviations: MIC, minimum inhibitory concentration; MBC, minimum bactericidal concentration; BUN, blood urea nitrogen; i.m., intramuscuscular; i.v., intravenous. 
bramycin therapy; patient 10 developed a pruritic maculopapular rash on the day tobramycin was discontinued. This rash persisted for several weeks and was present only in those areas covered by the patient's nylon nightgown; the relationship of this rash to tobramycin therapy was not certain. There were no other apparent adverse effects of tobramycin therapy in this group of patients; audiograms performed serially in eight patients showed no hearing losses.

Pharmacological data. Eleven patients received tobramycin intravenously (i.v.) and four intramuscularly (i.m.). A dose of 1 to $1.5 \mathrm{mg} / \mathrm{kg}$ was administered every $8 \mathrm{~h}$ if renal function was normal and at longer intervals if renal function was impaired. Only one of our patients (patient 15) was azotemic when therapy was begun (Table 2).

The range of serum concentrations of tobramycin $2 \mathrm{~h}$ after parenteral doses was much greater following i.v. administration $(0.16$ to 20 $\mu \mathrm{g} / \mathrm{ml})$ than after i.m. injection (1.2 to 11 $\mu \mathrm{g} / \mathrm{ml}$ ); however, the mean serum concentrations of tobramycin were $5.1 \mu \mathrm{g} / \mathrm{ml}$ at $2 \mathrm{~h}$ for both routes of administration (Table 2). Eight hours after i.m. injection serum concentrations of tobramycin ranged from 0.00 to $6.4 \mu \mathrm{g} / \mathrm{ml}$ with a mean of $1.9 \mu \mathrm{g} / \mathrm{ml}$; the range of concentrations $8 \mathrm{~h}$ after i.v. administration was 0.00 to $10 \mu \mathrm{g} / \mathrm{ml}$ with a mean of $2.4 \mu \mathrm{g} / \mathrm{ml}$. High concentrations of tobramycin were present in urine with ranges of 3.9 to $350 \mu \mathrm{g} / \mathrm{ml}$ and 3 to $240 \mu \mathrm{g} / \mathrm{ml} 2$ and $8 \mathrm{~h}$ after administration of tobramycin, respectively.

\section{DISCUSSION}

In the cases presented, the bacteriological diagnoses were clear and thus clinical responses to tobramycin therapy easily could be monitored. Although all the patients had underlying diseases, thereby increasing mortality of infections due to gram-negative bacilli $(2,7,13)$, tobramycin proved to be a very effective antimicrobial agent.

Patient 7 had bacteremia with both an $E$. coli and an enterococcus. Moellering et al. (21) noted synergy of tobramycin and penicillin $G$, equivalent to the synergy of gentamicin and penicillin G, against all strains of blood culture isolates of enterococci that were tested. Patient 2 with aplastic anemia and bacteremia due to Klebsiella pneumoniae developed a superinfection with $S$. aureus on the sixth day of therapy. The patient died despite oxacillin therapy. Simon et al. (26) reported that tobramycin was not as active in vitro as gentamicin against $S$. aureus.
All our patients with pulmonary or urinary tract infections responded well to tobramycin therapy. Gentamicin has been used successfully to treat pulmonary infections although some authors have reported greater efficacy in the treatment of urinary tract infections $(18,25)$.

High concentrations of tobramycin were present in urine of treated patients. Naber et al. (22) administered tobramycin to 18 elderly male patients with urinary tract infections; 10 had normal renal function and 8 had impaired renal function. However, these authors did not report the clinical details for their patients or the results of therapy. They showed that the renal clearance of tobramycin was $92 \%$ of the glomerular filtration rate. At a dose of $1 \mathrm{mg} / \mathrm{kg}$ i.m. every 6 to $8 \mathrm{~h}$ a urine concentration of over 100 $\mu \mathrm{g} / 100 \mathrm{ml}$ was obtained at 0 to $6 \mathrm{~h}$ after injection of tobramycin. Naber et al. (22) suggested that, in patients with impaired renal function, a loading dose of $1 \mathrm{mg}$ of tobramycin per $\mathrm{kg}$ be administered followed by doses at an interval (in hours) obtained by multiplying the serum creatinine level by 6 .

The serum level of gentamicin is related inversely to the hematocrit (24). We could not document such a relationship with tobramycin in this limited study. Repeated i.m. doses of gentamicin have been associated with unpredictable serum levels presumably due to reinjection at the same site (28). The variable serum concentrations we found after i.v. infusion are explained readily by the method of administration. The drug was administered by the ward nurses via soluset. Although the nurses were instructed to infuse the drug over a $30-\mathrm{min}$ period, the actual duration of the infusion was extremely variable. Furthermore, some of the i.v. lines were infiltrated. Simon et al. (26) reported that tobramycin given as a continuous infusion at a dose of $6.6 \mathrm{mg} / \mathrm{h}$ yielded a peak concentration of $1.06 \pm 0.16 \mu \mathrm{g} / \mathrm{ml} ; 40 \mathrm{mg}$ and $80 \mathrm{mg}$ administered i.m. gave peak serum concentrations of 3.67 and $2.41 \mu \mathrm{g} / \mathrm{ml}$, respectively, at $0.5 \mathrm{~h}$ after injection. These authors also found that the serum half-lives of gentamicin and tobramycin $(1.6 \mathrm{~h})$ and the volumes of distribution were quite similar. Meyers and Hirschman (20) reported peak serum concentrations of 5.5 and $6.02 \mu \mathrm{g}$ of tobramycin per $\mathrm{ml}$ after $1 \mathrm{mg} / \mathrm{kg}$ and $1.5 \mathrm{mg} / \mathrm{kg}$ i.v. doses, respectively, infused over a 30 - to 45 - $\mathrm{min}$ period in healthy volunteers. Gentamicin given at similar doses yielded serum concentrations equivalent to those of tobramycin (20).

Although tobramycin shares the nephrotoxicity and ototoxicity of other aminoglycosides, the 
only adverse reaction noted in this study was eosinophilia in one patient. Another patient developed a pruritic rash when tobramycin was discontinued but the relationship of this eruption to tobramycin therapy was doubtful. Ototoxicity with gentamicin has been related to dose level, duration of therapy, renal function, and patient age $(12,27)$. Although the factors relating to ototoxicity with tobramycin have not as yet been fully determined, in our patients the dose never exceeded $4.5 \mathrm{mg}$ per $\mathrm{kg}$ per $24 \mathrm{~h}$ and the duration of therapy was not greater than 19 days. It has been suggested that peak serum levels of gentamicin of 8 to $12 \mu \mathrm{g} / \mathrm{ml}$ should not be exceeded if toxicity is to be avoided (12). The factors related to nephrotoxicity of gentamicin are also uncertain (27). Close monitoring of the patient seems to be very important. Neuromuscular blockade is another hazard of aminoglycoside therapy (23). This problem rarely is encountered with gentamicin (16). As with other aminoglycosides we recommend caution in the use of tobramycin in patients with neuromuscular disease. Only one of our patients had significant azotemia when therapy with tobramycin was begun and the dosage schedule was modified similarly to that recommended for gentamicin in renal impairment (17).

All the gram-negative organisms encountered in this study were inhibited by $10 \mu \mathrm{g}$ or less of tobramycin per $\mathrm{ml}$. Of the species of organisms cultured, Serratia marcescens generally is the most resistant to tobramycin (6). Strains of $S$. marcescens tend to be more sensitive to gentamicin than to tobramycin (4).

We conclude that tobramycin can be safely employed parenterally to treat patients severely ill with gram-negative bacterial infections. Tobramycin is more active in vitro against strains of Pseudomonas than gentamicin $(5,6,19)$ but a clinical comparison of tobramycin and gentamicin in the treatment of Pseudomonas infections has not yet been reported. Dienstag and Neu (6) reported in vitro synergy of tobramycin and carbenicillin against strains of Pseudomonas. Crowe and Sanders (4) found no crossresistance between gentamicin and tobramycin for strains of $E$. coli, both indole-positive and indole-negative proteus, $\boldsymbol{E}$. aerogenes, and Serratia sp. In an in vitro study, Meyers and Hirschman (19) demonstrated that strains of Pseudomonas selected for resistance to tobramycin became very resistant to gentamicin. Organisms selected for resistance to gentamicin also became resistant to tobramycin although the minimum inhibitory concentrations of the resistant organisms to tobramycin were one-half those of gentamicin. Our data suggest that further clinical trials of tobramycin are warranted.

\section{ACKNOWLEDGMENTS}

This work was supported by a Public Health Service grant (T01 AI0041-03) from the National Institute for Allergy and Infectious Diseases and a grant from the Lilly Research Laboratory.

We thank Virginia Funke and Ilona Kovacs for their excellent technical assistance.

\section{LITERATURE CITED}

1. Altmeier, W. A., J. C. Todd, and W. E. Inge. 1967. Gram-negative septicemia: a growing threat. Ann. Surg. 166:530-542.

2. Bryant, E. M., A. F. Hood, C. E. Hood, and M. G Koenig. 1971. Factors affecting mortality of gram-negative rod bacteremia. Arch. Intern. Med. 127:120-128.

3. Cox, C., and L. L. Harrison. 1971. Comparison of gentamicin and polymyxin B-kanamycin in therapy of bacteremia due to gram-negative bacilli. J. Infect. Dis. 124S: $156-163$

4. Crowe, C. C., and E. Sanders. 1972. Is there complete cross-resistance of gram-negative bacilli to gentamicin and tobramycin? Antimicrob. Ag. Chemother. 2:415-416.

5. DelBene, V. E., and W. E. Farrar. 1972. Tobramycin: in vitro activity and comparison with kanamycin and gentamicin. Antimicrob. Ag. Chemother. 1:340-342.

6. Dienstag, J., and H. C. Neu. 1972. In vitro studies of tobramycin, an aminoglycoside antibiotic. Antimicrob. Ag. Chemother. 1:41-45.

7. Dupont, H. L., and W. W. Spink. 1969. Infections due to gram-negative organisms: an analysis of 860 patients with bacteremia at the University of Minnesota Medical Center, 1958-1966. Medicine (Baltimore) 48:302-322.

8. Finland, M., W. F. Jones, and M. W. Barnes. 1959 Occurrence of serious bacterial infections since introduction of antibacterial agents. J. Amer. Med. Ass. 170:2188-2197.

9. Freid, M. A., and K. L. Vosti. 1968. The importance of underlying disease in patients with gram-negative bacteremia. Arch. Intern. Med. (Chicago) 121:418-423.

10. Hodgin, V. G., and J. P. Sanford. 1965. Gram-negative rod bacteremia. an analysis of 100 patients. Amer. J. Med. 39:952-960

11. Holloway, W., and W. Taylor. 1971. Gentamicin and kanamycin in the treatment of gram-negative sepsis. A comparative study. J. Infect. Dis. 124S: $180-184$.

12. Jackson, G. G., and G. Arcieri. 1971. Ototoxicity of gentamicin in man: a survey and controlled analysis of clinical experience in the United States. J. Infect. Dis. 124S: $130-137$

13. Jackson, G. G., and L. Riff. 1971. Pseudomonas bac teremia: pharmacologic and other bases for failure of treatment with gentamicin. J. Infect. Dis. 124S: $185-191$.

14. Martin, C. M., A. J. Cuomo, M. J. Geraghty, J. R. Zager, and T. C. Mandes. 1969. Gram-negative rod bacteremia. J. Infect. Dis. 119:506-517.

15. McCabe, W. E., and G. G. Jackson. 1962. Gram-negative bacteremia. I. Etiology and ecology. Arch. Intern. Med. 110:847-855.

16. McCloskey, R. V., W. E. Sanders, J. M. Garfunkle, H. M Levine, and G. G. Jackson. 1971. Symposium on gentamicin. III. Toxicity. Discussion. J. Infect. Dis. 124S: $154-155$.

17. McHenry, M. C., T. L. Gavan, T. W. Gifford, N. A Geurkink, R. A. Van Ommen, M. A. Town, and J. G. Wagner. 1971. Gentamicin dosages for renal insufficiency. Adjustments based on endogenous creatinine 
clearance and serum creatinine concentration. Ann. Intern. Med. 74:192-197.

18. McHenry, M. T., T. Gavan, R. Van Ommen, and W. Hawk. 1971. Therapy with gentamicin for bacteremic infections. Results with 53 patients. J. Infect. Dis. 124S: $164-173$.

19. Meyers, B. R., and S. Z. Hirschman. 1972. Tobramycin: in vitro antibacterial spectrum of a new aminoglycoside. J. Clin. Pharmacol. 12:313-320.

20. Meyers, B. R., and S. Z. Hirschman. 1972. Pharmacologic studies on tobramycin and comparison with gentamicin. J. Clin. Pharmacol. 12:321-324.

21. Moellering, R. C., C. Wennersten, and A. Weinstein. 1973. Penicillin-tobramycin synergism against enterococci: a comparison with penicillin and gentamicin. Antimicrob. Ag. Chemother. 4:526-529.

22. Naber, K. G., S. R. Westernfelder, and P. O. Madsen. 1973. Pharmacokinetics of the aminoglycoside antibiotic tobramycin in humans. Antimicrob. Ag. Chemother. 3:469-473.
23. Ream, C. R. 1963. Respiratory and cardiac arrest after intravenous administration of kanamycin with reversal of toxic effects by neostigmine. Ann. Intern. Med. 59:384-387.

24. Riff, L., and G. G. Jackson. 1971. Pharmacology of gentamicin in man. J. Infect. Dis. 124S:98-105.

25. Shimizu, K. L. 1969. Clinical experience with gentamicin in Japan. J. Infect. Dis. 119:448-452.

26. Simon, V. K., E. U. Mosinger, and V. Malerczy. 1973. Pharmacokinetic studies of tobramycin and gentamicin. Antimicrob. Ag. Chemother. 3:445-450.

27. Wilfert, J., I. Burke, H. A. Bloomer, and C. Smith. 1971. Renal insufficiency associated with gentamicin therapy. J. Infect. Dis. 124S:148-155.

28. Winters, R. E., K. D. Litwak, and W. Hewitt. 1971. Relation between dose and levels of gentamicin in blood. J. Infect. Dis. 124S:90-95.

29. Yow, E. M. 1955. Clinical significance of rising incidence of infections due to gram-negative bacilli. Postgrad. Med. 17:413-419. 